\title{
Abscisic acid and desiccation tolerance in oil palm (Elaeis guineensis Jacq.) somatic embryos
}

\author{
Frédérique Aberlenc Bertossi*, Nathalie Chabrillange, \\ Yves DUVAL
}

Laboratoire GeneTrop, Centre IRD, 911, avenue Agropolis, BP 5045, 34032 Montpellier Cedex 01, France

\begin{abstract}
The effect of exogenous abscisic acid (ABA) on the desiccation tolerance, soluble sugar contents and germination rates of oil palm somatic embryos was studied. ABA was added during the development or germination of the somatic embryos. The treatments had no effect on embryo dry weights or water and sucrose contents. In contrast, monosaccharide levels decreased in ABA-treated embryos and raffinose was detected in embryos treated for 6 weeks with increasing concentrations of ABA (from 5 to $25 \mu \mathrm{M}$ ). ABA significantly improved embryo tolerance to rapid desiccation. Embryos treated with $25 \mu \mathrm{M}$ ABA exhibited survival rates higher than that of the control. The 2-week ABA treatment induced a delay in shoot emission during embryo germination on hormone-free media. In contrast, embryos treated with $50 \mu \mathrm{M}$ ABA displayed no germination. The presence of $\mathrm{ABA}$ in germination media induced inhibition of embryo shoot emission. These results suggest that ABA plays a role in the maturation and the acquisition of desiccation tolerance of oil palm somatic embryos.
\end{abstract}

somatic embryo / desiccation tolerance / abscisic acid / sugar / Elaeis guineensis Jacq.

Résumé - Acide abscissique et tolérance à la dessiccation des embryons somatiques de palmier à huile (Elaeis guineensis Jacq.). L'effet de l'acide abscissique $(\mathrm{ABA})$ sur la tolérance à la dessiccation des embryons somatiques de palmier à huile, leur contenu en sucres solubles et leur taux de germination a été étudié. L'ABA a été ajouté pendant le développement ou la germination des embryons somatiques. L'ABA n'a pas d'effet significatif sur le poids sec, la teneur en eau et en saccharose des embryons. En revanche, les teneurs en monosaccharides sont

* Correspondence and reprints

E-mail: aberlenc@mpl.ird.fr 
diminuées dans les embryons traités à l'ABA et le raffinose est détecté dans des embryons traités pendant 6 semaines avec des concentrations croissantes en ABA (de 5 à $25 \mu \mathrm{M}$ ). L'ABA améliore la tolérance des embryons à la dessiccation rapide. Les embryons traités avec $25 \mu \mathrm{M}$ d'ABA ont un taux de survie supérieur à celui des embryons témoins. Le traitement des embryons avec $25 \mu \mathrm{M}$ d'ABA provoque un retard dans l'émission des pousses feuillées par rapport aux témoins lors de la germination sur milieu sans hormone. En revanche, aucune germination n'est observée pour les embryons traités avec $50 \mu \mathrm{M}$ d'ABA. La présence d'ABA dans le milieu de germination des embryons provoque l'inhibition de l'émission des pousses feuillées. Ces résultats suggèrent un rôle de l'ABA dans la maturation et la tolérance à la dessication des embryons somatiques de palmier à huile.

embryon somatique / tolérance à la dessiccation / acide abscissique / sucres / Elaeis guineensis Jacq.

\section{INTRODUCTION}

The aim of this work was to describe the role of ABA in resistance to dehydration, a key step in the majority of the conservation protocols for in vitro cultivated plant organs. ABA plays an essential role in seed development and maturation processes [8]. Endogenous levels are low at the beginning of seed development, increase until the initiation of maturity and then decrease during dehydration. ABA is involved in the induction of seed dormancy during seed development and prevents early germination and mobilisation of storage products [8]. ABA is thought to be involved in the desiccation tolerance of orthodox seeds by inducing LEA (Late Embryogenesis Abundant) protein synthesis [14]. These proteins are synthesised during the development of the embryos and accumulate at the end of their maturation phase. Their hydrophilic nature, together with the presence of repeated sequences of amino acids, is thought to give them a role in the protection of tissues during anhydrobiosis [5].

The addition of ABA to the culture media of somatic embryos induced complete desiccation tolerance in alfalfa $[10]$ and carrot $[6,16]$. Tetteroo et al. [16] underlined the importance of the developmental stages, exogenous ABA, drying and rehydration modes for successful desiccation tolerance of carrot somatic embryos [16]. ABA-treated carrot embryos desiccated with silica gel were stored for 169 weeks at $-25^{\circ} \mathrm{C}[13]$.

Oil palm somatic embryos produced from embryogenic suspension cultures [1] were sensitive to desiccation, which limited their storage potential. In previous work, we showed that ABA enhanced the accumulation of storage proteins [11]. In this paper, we present data concerning the effect of $\mathrm{ABA}$ on the survival of somatic embryos rapidly desiccated on silica gel. The effects of ABA treatment on sugar contents and germination rates are also reported. 


\section{MATERIALS AND METHODS}

\subsection{Plant materials}

Somatic embryos were regenerated from embryogenic suspensions initiated from foliar explants of hybrid dura $\times$ pisifera oil palms supplied by the IDEFOR research station at La Mé in Côte d'Ivoire. Embryogenic clusters were subcultured monthly as described by de Touchet et al. [18]. Embryogenesis was achieved after transfer of cell clusters to basal medium supplemented with $30 \mathrm{~g} \cdot \mathrm{L}^{-1}$ sucrose and $0.5 \mathrm{~g} \cdot \mathrm{L}^{-1}$ casein hydrolysate according to Aberlenc Bertossi et al. [1]. Embryo development was induced after the plating of cell aggregates in Petri dishes (diameter $9 \mathrm{~cm}$ ) containing $20 \mathrm{ml}$ of the same medium gelled with $8 \mathrm{~g} \cdot \mathrm{L}^{-1}$ agar (Agar-agar, Sigma, USA). Cultures were grown under 12 -h light at $45 \mu \mathrm{mol} \cdot \mathrm{m}^{-2} \cdot \mathrm{s}^{-1}$ at $27^{\circ} \mathrm{C}$ and were subcultured weekly for 8 weeks. Benzyl adenine $(5 \mu \mathrm{M})$ was added during the first week.

\subsection{Germination}

Shoot emission was obtained by transfer of 20 epidermised embryos to Petri dishes containing $20 \mathrm{ml}$ of the same medium gelled with $2 \mathrm{~g} \cdot \mathrm{L}^{-1}$ Phytagel (Sigma, USA) and subcultured every two weeks for two months. In contrast with seeds, plant development from oil palm somatic embryos starts from the apical meristem in these culture conditions [18]. In this paper, germination percentages were calculated for embryos exhibiting single shoots among surviving embryos. Multiple shoots from polyembryonic structures were not taken into account. After the 2-month germination period, mortality was evaluated by the percentage of embryos that were brown and showed no development.

\subsection{ABA treatments}

\section{ABA supply during embryo development}

Several times during somatic embryo development, various concentrations of filter-sterilised ABA were added to media after autoclaving, following the design described in Table I. Treatments $0,1,2,3$ and $0,4,5,6$ were performed in 2 separate experiments.

\section{ABA supply during embryo germination}

Somatic embryos produced on ABA-free media were collected during the 7 th week after plating and subcultured on media supplemented with 0,25 and $50 \mu \mathrm{M}$ ABA under germination conditions. 


\subsection{Desiccation tolerance}

After treatments 0, 2 and 3 (Tab. I), embryos were collected and placed on sterilised filter papers on silica gel (Fisher Scientific, France) in glass containers. Embryos were desiccated for 2, 3 and $4 \mathrm{~h}$. Water contents and dry weights were calculated after lyophilisation. For estimation of survival after dehydration, embryos were placed under germination conditions. After 2 weeks, the somatic embryos were recorded as viable when growth was detectable.

Table I. ABA concentrations used during embryo development. Each value indicates the ABA concentration $(\mu \mathrm{M})$ in media.

\begin{tabular}{ccccccccc}
\hline ABA & \multicolumn{8}{c}{ Number of weeks after plating } \\
\cline { 2 - 9 } Treatment & 1 & 2 & 3 & 4 & 5 & 6 & 7 & 8 \\
\hline 0 & 0 & 0 & 0 & 0 & 0 & 0 & 0 & 0 \\
1 & 0 & 0 & 0 & 0 & 0 & 10 & 10 & 0 \\
2 & 0 & 0 & 0 & 0 & 0 & 25 & 25 & 0 \\
3 & 0 & 0 & 0 & 0 & 0 & 50 & 50 & 0 \\
4 & 0 & 0 & 0.1 & 0.1 & 2.5 & 2.5 & 5 & 5 \\
5 & 0 & 0 & 2.5 & 2.5 & 5 & 5 & 10 & 10 \\
6 & 0 & 0 & 5 & 5 & 10 & 10 & 25 & 25 \\
\hline
\end{tabular}

\subsection{Soluble sugar analyses}

Embryos collected after treatments 0, 2 and 3 (Tab. I) were lyophilised. They were reduced to powder and $10 \mathrm{mg}$ were extracted three times in succession in $1 \mathrm{ml} 80 \%$ ethanol, heated at $80{ }^{\circ} \mathrm{C}$ for $20 \mathrm{~min}$ and centrifuged at $5000 \mathrm{~g}$ for 10 min. Lactose was used as internal standard. The supernatants were pooled and evaporated under vacuum to dryness. Extracts were redissolved in distilled water and filtered through a $0.2 \mu \mathrm{m}$ mesh. Sugar contents were estimated using anion exchange chromatography coupled with pulsed amperometric detection (Dionex Chromatography Co). After dilution, samples were injected into a Carbo-Pac PA1 column and eluted with sodium hydroxide. Sugar contents were calculated after peak area integration by comparison with calibration curves established for each sugar.

\subsection{Statistical analyses}

All data were collected in triplicate for 20 embryos. One-way analyses of variance were used to test for the effects of ABA on sugar content and germination rate. Two-way analysis was used to test for the effect of the duration of desiccation on water content and survival percentage, and the interaction between these two factors. The Newman-Keuls test was used for multiple comparisons of categorical means $[9,12]$. 


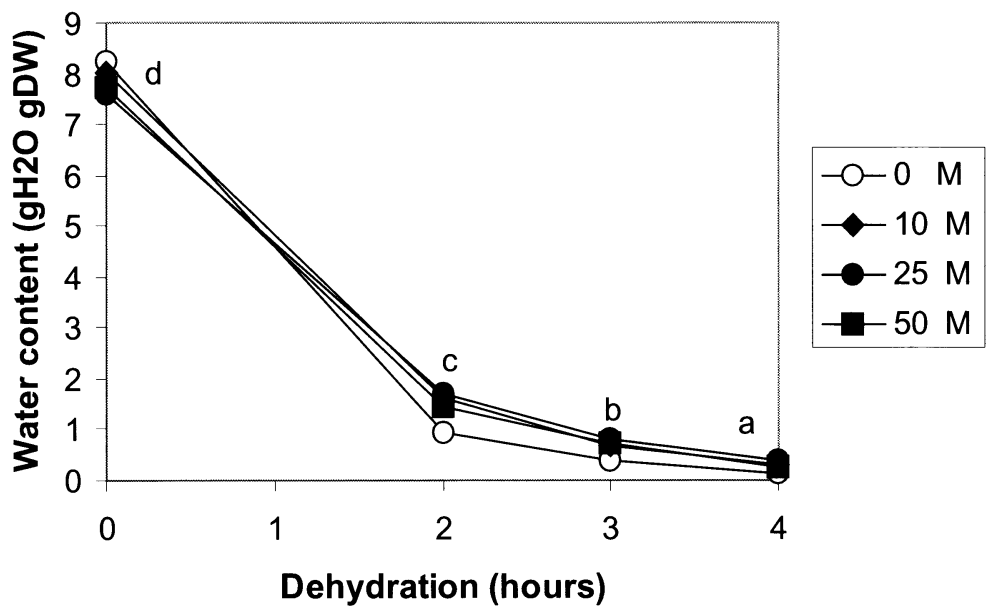

Figure 1. Effect of 2-week ABA treatment (see Tab. I) after a 5-week development period on embryo water content during dehydration. Values are means of triplicate measurements. The same letters indicate homogeneous groups.

\section{RESULTS}

\subsection{Somatic embryo development and desiccation tolerance}

After 2 weeks of ABA treatment (1 to 3 , Tab. I), ABA had no significant effects on embryo dry weight or water contents which were stable at around $1 \mathrm{mg}$ per embryo and $8 \mathrm{gH}_{2} \mathrm{O} \cdot \mathrm{g}^{-1} \mathrm{DW}$, respectively. Embryos were subjected to rapid drying before measurement of survival and water content. During dehydration, control and ABA-treated embryos displayed the same pattern of decrease in water content (Fig. 1). After $2 \mathrm{~h}$, embryos had lost most of their water and after $4 \mathrm{~h}$ the water content has fallen to $0.4 \mathrm{gH}_{2} \mathrm{O} \cdot \mathrm{g}^{-1} \mathrm{DW}$. ABA increased survival rates under rapid drying (Fig. 2). From the second hour of desiccation, embryos treated with $25 \mu \mathrm{M}$ ABA withstood dehydration significantly better than untreated material.

\subsection{Sugar contents}

ABA affected the sugar metabolism in somatic embryos (treatments 1 to 6 ). Monosaccharide (glucose and fructose) contents were found to be significantly reduced in ABA-treated embryos (Tabs. II and III). The sucrose contents were not affected in embryos treated for longer with increasing ABA concentrations (treatment 6, Tab. III), but raffinose, absent in control embryos, was detected. This oligosaccharide amounted to $5 \mathrm{mg} \cdot \mathrm{g}^{-1} \mathrm{DW}$ in treated embryos. 


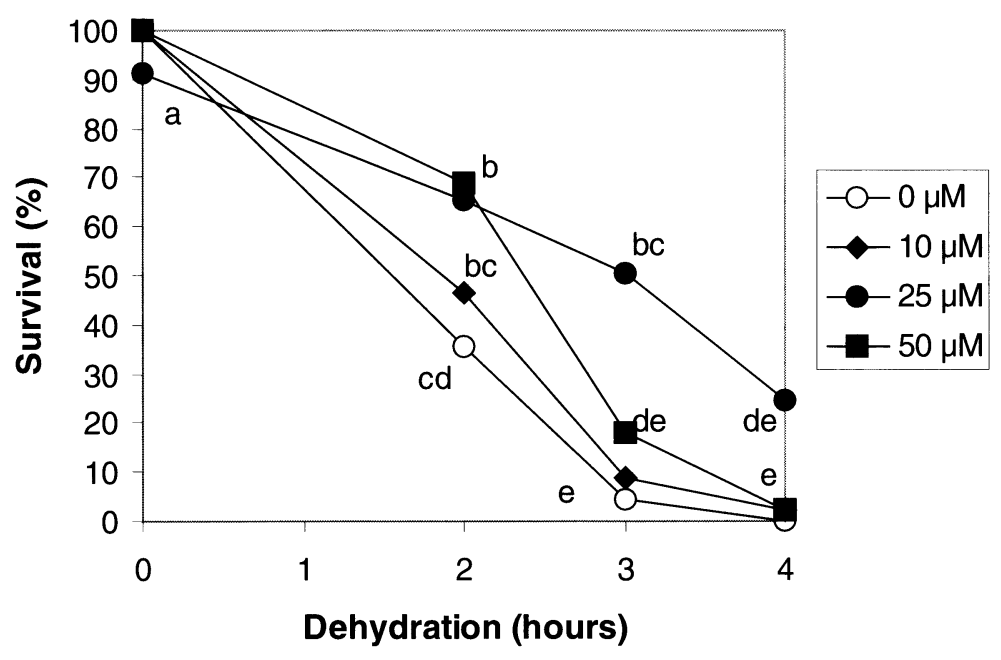

Figure 2. Effect of 2-week ABA treatment (see Tab. I) after a 5-week development period on embryo survival rate during dehydration. Values are means of triplicate measurements. The same letters indicate homogeneous groups.

Table II. Effect of 2-week ABA treatment (see Tab. I) after a 5-week development period on embryo sugar content. Values are means of triplicate measurements. The same letters indicate homogeneous groups.

\begin{tabular}{cccc}
\hline \multirow{2}{*}{ ABA } & \multicolumn{3}{c}{ Sugar contents $\left(\mathrm{mg} \cdot \mathrm{g}^{-1}\right.$} \\
\cline { 2 - 4 } Treatment & Glucose & Fructose & Sucrose \\
0 & $8.1 \mathrm{~b}$ & $7.9 \mathrm{~b}$ & $27.5 \mathrm{a}$ \\
2 & $4.1 \mathrm{a}$ & $3.7 \mathrm{a}$ & $25.7 \mathrm{a}$ \\
3 & $5.6 \mathrm{a}$ & $5.2 \mathrm{a}$ & $33.6 \mathrm{a}$ \\
\hline
\end{tabular}

Table III. Effect of 6-week ABA treatment (see Tab. I) at increasing concentrations after a 2-week development period on embryo sugar content. Values are means of duplicate measurements.

\begin{tabular}{ccccc}
\hline ABA & \multicolumn{4}{c}{ Sugar contents $\left(\mathrm{mg} \cdot \mathrm{g}^{-1} \mathrm{DW}\right)$} \\
\cline { 2 - 5 } Treatment & Glucose & Fructose & Sucrose & Raffinose \\
0 & $6 \mathrm{~b}$ & $25.39 \mathrm{~b}$ & $93.62 \mathrm{a}$ & $0 \mathrm{a}$ \\
4 & $2.99 \mathrm{a}$ & $9.08 \mathrm{a}$ & $100.94 \mathrm{a}$ & $0 \mathrm{a}$ \\
5 & $2.66 \mathrm{a}$ & $6.43 \mathrm{a}$ & $97.99 \mathrm{a}$ & $0 \mathrm{a}$ \\
6 & $1.56 \mathrm{a}$ & $1.94 \mathrm{a}$ & $133.72 \mathrm{a}$ & $5.19 \mathrm{~b}$ \\
\hline
\end{tabular}

\subsection{Germination}

Embryos treated with ABA for 2 weeks (treatments 1-3) were placed on a hormone-free medium for estimation of the effect of the treatments on subsequent germination. Control embryos showed no loss of viability and the 


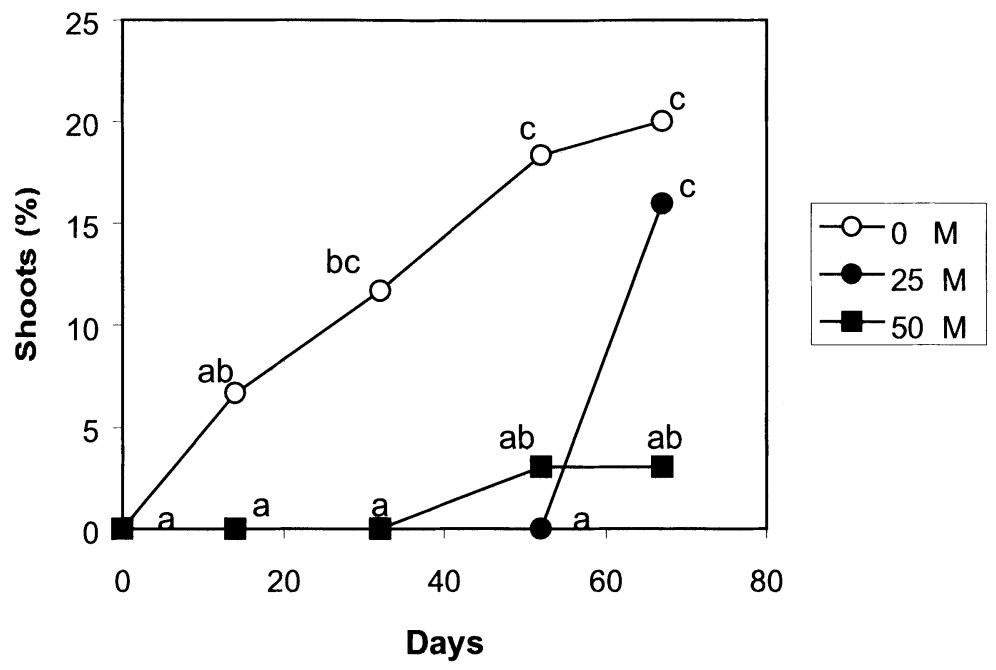

Figure 3. Effect of 2-week ABA treatment (see Tab. I) after a 5-week development period on embryo shoot emission. Values are means of triplicate measurements. The same letters indicate homogeneous groups.

percentage of single shoots produced increased to $21 \%$ after two months of germination (Fig. 3). Treatments with 25 and $50 \mu \mathrm{M}$ ABA caused $20 \%$ and $50 \%$ embryo mortality, respectively. Embryos surviving after the $25 \mu \mathrm{M} \mathrm{ABA}$ treatment exhibited a delay in the emission of single shoots. They did not germinate during the 50 first days on the germination medium but reached a germination percentage as high as that of the control after 67 days. In contrast, embryos treated with $50 \mu \mathrm{M}$ ABA did not germinate. ABA applied during the germination period to 7-week-old embryos grown on ABA-free medium caused low embryo mortality (10\%). However, the presence of 25 or $50 \mu \mathrm{M} \mathrm{ABA}$ in the germination medium inhibited shoot emission (Fig. 4).

\section{DISCUSSION}

Our results clearly demonstrate that ABA increases oil palm embryo tolerance to rapid desiccation and modifies soluble carbohydrate contents and germination rates.

After ABA treatment, oil palm somatic embryos display a decrease in glucose and fructose contents and the appearance of raffinose. A decrease in monosaccharides and an increase in di- and trisaccharide contents are commonly described during seed maturation [19]. This feature has also been described in ABA-treated somatic embryos of Daucus carota [17].

Sugars may be involved in anhydrobiosis via membrane stabilisation or the formation of a glassy state $[4,21]$. Sucrose and oligosaccharides may stabilise 


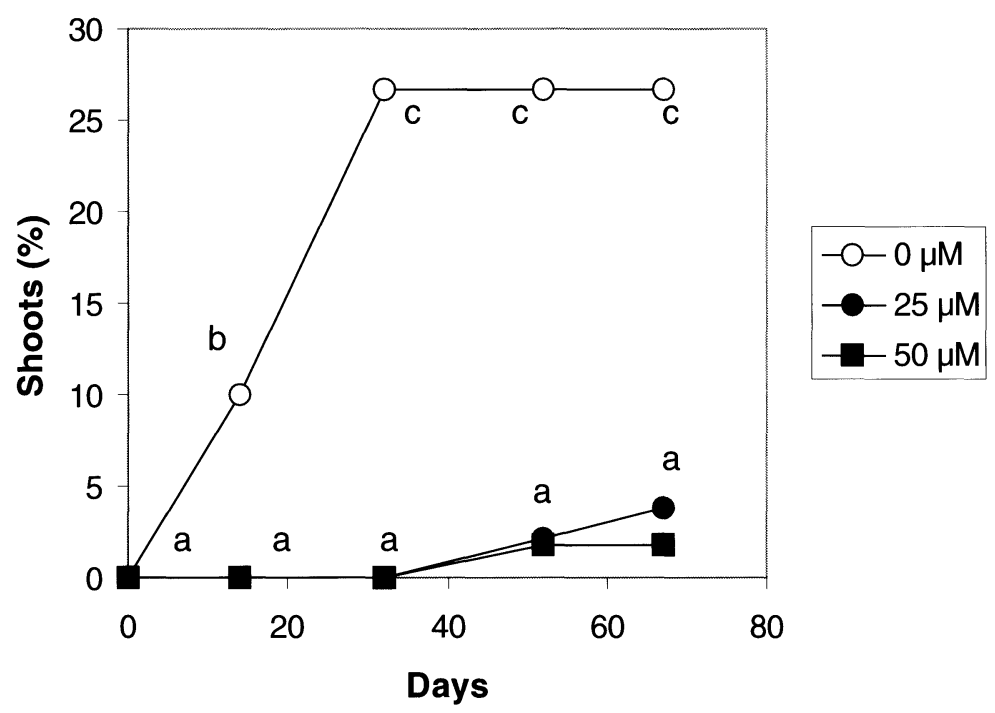

Figure 4. Effect of ABA treatment (see Tab. I) during germination on embryo shoot emission. Values are means of triplicate measurements. The same letters indicate homogeneous groups.

the glassy state whereas monosaccharides could disrupt it. The acquisition of desiccation tolerance throughout zygotic embryo development is associated with the synthesis of raffinose in several species [2,3]. Sucrose, raffinose and stachyose are also present in mature oil palm zygotic embryos [15]. ABA induces the synthesis of raffinose in somatic embryos but no trace of stachyose was detected. Carrot embryoids treated with high ABA $(38 \mu \mathrm{M})$ became quiescent and tolerant to desiccation, ceased sugar uptake and decreased respiration rates [17]. Tetteroo et al. hypothesise that ABA affects the substrate competition between glycolysis and the formation of sucrose or trisaccharide umbelliferose. Nevertheless, the increase in oil palm somatic embryo tolerance to dehydration after the 2-week ABA treatment is not associated with the synthesis of oligosaccharide.

Exogenous $\mathrm{ABA}$ inhibits the germination and favours the maturation of oil palm somatic embryos and several other species. In ABA-deficient maize developing kernels, a GA deficiency suppresses vivipary [20] and the authors proposed that the $\mathrm{ABA} / \mathrm{GA}$ ratio controls the orientation of the developmental programme leading to germination or maturation. The study of Arabidopsis thaliana mutants supports the participation of ABA in dormancy [7]. ABA could also block germination in oil palm somatic embryos by inducing dormancy.

ABA induces in somatic embryos several physiological events described during zygotic embryogenesis. Nevertheless, in the case of oil palm, ABA treatments are not sufficient to induce complete desiccation tolerance. Earlier and 
longer treatments could be necessary to guide embryo development towards the maturation programme. Several other factors controlling late embryogenesis in seeds may be lacking in the somatic embryo environment. High osmotica or slow dehydration in combination with ABA may allow the set up of the maturation programme and the induction of complete desiccation tolerance in oil palm somatic embryos, thus facilitating their conservation.

\section{ACKNOWLEDGEMENTS}

This work was supported by a grant from the Bureau des ressources génétiques, France. We thank N. Djegui and B. Nouy for providing plant material and S. Doulbeau for sugar assays.

\section{REFERENCES}

[1] Aberlenc Bertossi F., Noirot M., Duval Y., BA enhances the germination of oil palm somatic embryos derived from embryogenic suspension cultures, Plant Cell Tiss. Org. Cult. 56 (1999) 53-57.

[2] Black M., Corbineau F., Grzesik M., Guy P., Côme D., Carbohydrate metabolism in the developing and maturing wheat embryo in relation to its desiccation tolerance, J. Exp. Bot. 47 (1996) 161-169.

[3] Brenac P., Hobowicz M., Downer S.M., Dickerman A.M., Smith M.E. Obendorf R.L., Raffinose accumulation related to desiccation tolerance during maize (Zea mays L.) seed development and maturation, J. Plant Physiol. 150 (1997) 481-488.

[4] Crowe J.H., Crowe L.M., Carpenter J.F., Wistrom C.A., Stabilization of dry phospholipid bilayers and proteins by sugars, Biochem. J. 242 (1987) 1-10.

[5] Dure L. III, Crouch M., Harada J., Ho T.H.D., Mundy J., Quatrano R., Thomas T., Sung Z.R., Common amino acid sequence domains among the LEA proteins of higher plants, Plant Mol. Biol. 12 (1989) 475-486.

[6] Iida Y., Watabe K.I., Kamada H., Harada H., Effect of abscisic acid on the induction of desiccation tolerance in carrot somatic embryos, Plant Physiol. 140 (1992), 356-360.

[7] Karssen C.M., Brinkhorst-vanderSwan D.L.C., Breekland A.E., Koornneef M., Induction of dormancy during seed development by endogenous abscisic acid: studies on abscisic acid deficient genotypes of Arabidopsis thaliana (L.) Heynh, Planta 157 (1983) 158-165.

[8] Kermode AR., Regulatory metabolisms in the transition from seed development to germination: interactions between the embryo and the seed environment, in: Kigel J., Galili G. (Eds.), Seed development and germination, Marcel Dekker, New York, 1995, pp. 273-332.

[9] Keuls M., The use of a studentized range in connection with analysis of variance, Euphytica 1 (1952) 112-122.

[10] McKersie B.D., Van Acker S.D.N., Artificial seeds: a comparison of desiccation tolerance in zygotic and somatic embryos, in: Shargool P.D., Ngo T.T. (Eds.), 
Biotechnological application of plant culture, CRC Press, Boca Raton, Florida, 1994, pp. 129-150.

[11] Morcillo F., Aberlenc-Bertossi F., Hamon S., Duval Y., Influence of culture conditions on $7 \mathrm{~S}$ globulins accumulation in somatic embryos of oil palm (Elaeis guineensis Jacq.), Acta Hort. 461 (1998) 173-183.

[12] Newman D., The distribution of range in samples from a normal population expressed in terms of an independent estimate of standard deviation, Biomet. 3 (1939) 20-30.

[13] Shiota H., Tachibana K., Watabe K., Kamada H., Successful long-term preservation of abscisic-acid-treated and desiccated carrot somatic embryos, Plant Cell Rep. 18 (1999) 749-753.

[14] Skriver K, Mundy J., Gene expression in response to abscisic acid and osmotic stress, Plant Cell 2 (1990) 503-512.

[15] Steadman K.J., Pritchard H.W., Prakash M.D., Tissue specific soluble sugars in seeds as indicators of storage category, Annals Bot. 77 (1996) 667-674.

[16] Tetteroo F.A.A., Hoekstra F.A., Karssen C.M., Induction of complete desiccation tolerance in carrot (Daucus carota) embryoids, J. Plant Physiol. 145 (1995) 349-356.

[17] Tetteroo F.A.A., Peters A.H.L.J., Hoekstra F.A., Van der Plas L.H.W., Hagendoorn M.J.M., ABA reduces respiration and sugar metabolism in developing carrot (Daucus Carota L.) embryoids, J. Plant Physiol. 145 (1995) 477-482.

[18] Touchet (de) B., Duval Y., Pannetier C., Plant regeneration from embryogenic suspension culture of oil palm (Elaeis guineensis Jacq.), Plant Cell Rep. 10 (1991) 529-532.

[19] Vertucci C.W., Farrant J.M., Acquisition and loss of desiccation tolerance, in: Kigel J., Galili G. (Eds.), Seed development and germination, Marcel Dekker, New York, 1995, pp. 273-332.

[20] White C.N., Proebsting W.M., Hedden P., Rivin C.J., Gibberellins and seed development in maize. I. Evidence that gibberellin/abscisic acid balance governs germination versus maturation pathways, Plant Physiol. 122 (2000) 1081-1088.

[21] Williams R.J., Leopold A.C., The glassy state in corn embryos, Plant Physiol. 89 (1989) 977-981. 